\author{
Research Article \\ www.ijrap.net
}

\title{
SPIRITUAL CARE COMPETENCE OF NURSES: A PRE EXPERIMENTAL STUDY
}

K.R. Anoopa ${ }^{1 *}$, S. Vijayalakshmi ${ }^{2}$, R. Vijayaraghavan ${ }^{3}$

${ }^{1} \mathrm{PhD}$ Scholar, Saveetha University, Chennai, India

${ }^{2}$ Principal, Vignesh Nursing College, Tiruvannamalai, Chennai, India

${ }^{3}$ Director, Research Department, Saveetha University, Chennai, India

Received on: 10/05/17 Accepted on: 22/06/17

\begin{abstract}
*Corresponding author
E-mail: anoopasuresh@yahoo.co.in
\end{abstract}

DOI: 10.7897/2277-4343.083156

\begin{abstract}
Spiritual care is an inseparable element of nursing. Nurses have identified the importance of enhancing patient's spiritual health, and established nursing theories support holistic nursing care with special mention to spiritual component. The present study was undertaken to assess the effectiveness of spiritual care training program on spiritual care competence of nurses in a selected setting. A pre experimental, one group pretest-post test study design was used with repeated measures. 10 hours training program was given to 50 nurses working in the stroke unit selected for the study and Kruskal wallis one way analysis of variance on rank was used to compare the nurses competence on spiritual care from pre-test to post test 1,posttest 2 and post-test 3.Intervention was found to be effective in significantly improving spiritual care competence of nurses
\end{abstract}

Keywords: Spiritual care competence, nurses, spiritual care training

\section{INTRODUCTION}

Nurses play a significant role in providing holistic care to patients. Nurses have identified the importance of enhancing patient's spiritual health, and established nursing theories that support holistic nursing care with special mention to spiritual component. Formally spiritual care has been included in nursing curricula and nursing codes, but nursing educational institutions devote little attention to the development of competence of students in this domain of care. The result is unfamiliarity with spiritual care in the nursing profession and nurses being not well prepared for providing spiritual care ${ }^{1,2}$. Also accreditation agencies now mandate inclusion of spiritual care as a part of holistic care. Nurses doubt that their own spiritual /religious believes may interfere with that of patients while providing spiritual care. Thus nurses' awareness about their own spirituality and its relationship to care giving is an important factor that may influence the spiritual care competence of nurses. Need for spiritual care, which is a significant element of holistic approach ${ }^{3}$ can be identified for all patients but it is found as a priority need among patients with chronic illness who needs long term and rehabilitative care

\section{Statement of the problem}

A study to assess the effectiveness of spiritual care training program for nurses on their spiritual care competence

\section{Objectives}

- To assess the spiritual care competence of nurses before and after spiritual care training program.

- To compare the spiritual care competence of nurses before and after spiritual care training program.

\section{Research Hypotheses}

- H1: There will be a significant difference between spiritual care competence of nurses before and after spiritual care training program.

- H2: There will be a significant association between spiritual care competence and selected demographic variables of nurses.

\section{MATERIALS AND METHODS Research Approach and Design}

The present study adopted quantitative approach ${ }^{4}$ with pre experimental design to assess the effectiveness of spiritual care training program for nurses on spiritual care competence of nurses.

Sample: 50 registered nurses working in the stroke unit of the selected hospital setting was selected for the study

\section{Sampling technique}

Total enumerative sampling was used and all nurses who fulfilled inclusion and exclusion criteria were selected for the study

Inclusion criteria: All registered nurses working in the selected unit and willing to participate in the study

Exclusion criteria: Nurses who were on floating duty at the time of study and nurses who were non believers in spirituality.

\section{Tool}

Tool used for the study had two sections, Section A dealt with demographic variables of nurses and section B was the Spiritual Care Competence Scale ${ }^{5,6}$. It is a 27 item, self rated valid and reliable standardized questionnaire which tests nurses 
competency on six domains. These domains were labelled as: assessment and implementation of spiritual care (Cronbach's alpha 0.82), professionalization and improving quality of spiritual care (Cronbach's alpha 0.82), personal support and patient counseling (Cronbach's alpha 0.81), referral to professionals (Cronbach's alpha 0.79), attitude towards patient's spirituality (Cronbach's alpha 0.56) and communication (Cronbach's alpha 0.71). Higher the score, better will be the spiritual care competence of nurses.

\section{Data Collection process}

Phase I: Pre test data was collected on an individual basis from each participant at the end of shift duty. Spiritual care training program was planned in collaboration with continuing nursing education department and conducted in. class room setting of the hospital in two batches of 25 each.

Phase II: The 10 hours of Training Programme on Spiritual Care included topics on -Introduction to spiritual care in nursing, Grief process and patients responses, spiritual values in human relation, Nursing process application in relation to spiritual needs, Professional standards and quality assurance in spiritual care-nurses role. The training program that included exercises to study participants on value clarification, self awareness and development of nursing care plan based on a case scenario were given to study participants for two days (5hours/day) in collaboration with the in service education department of the hospital. It took 4 days to complete the training program

Phase III: Reinforcement was given using pamphlet on spiritual nursing care on Day 10 and Flyers were displayed in nurses stations of the selected units on day 15 . Post- test data were collected on $10^{\text {th }}$ day, $15^{\text {th }}$ day and $21^{\text {st }}$ day after completing training program

\section{Ethical Consideration}

The study was conducted after getting approval from Institutional Human Ethics Committee of Saveetha University (004/11/2013/IEC/SU dated 15 November 2013). Permission also was obtained from the selected setting-. Informed consent was obtained after clarification of doubts. Data collected were kept confidential, confidentiality assured and all the ethical principles were followed throughout the study.

\section{Statistical analysis}

Data was analyzed using descriptive and inferential statistics. Mean and SE were computed. Kruskal wallis one way analysis of variance on rank was used to compare the nurses competence on spiritual care from pre-test to post test 1 , post-test 2 and posttest 3. Chi square was used to find the association between spiritual care competence of nurses and selected demographic variables

\section{RESULTS}

All nurses were females.

Table 1: The scores obtained by nurses in various domains of Spiritual Care Competence Scale has shown a significant difference in the competence of nurses in all six domains as well as overall competence of spiritual care, before and after the training program. A significant difference was found between the scores obtained by nurses in pre-test 1 and post-test 1,2 and 3 on the domain 1-attitude toward patient spirituality $(\mathrm{H}=94.602, \mathrm{P}<0.001)$, domain 2-communication $(\mathrm{H}=69.765, \mathrm{P}<$ $0.001)$, domain 3- assessment and implementation of spiritual care. $(\mathrm{H}=113.160, \mathrm{P}<0.001)$, domain 4- Referral. $(\mathrm{H}=89.740$, $\mathrm{P}<0.001$ ), domain 5- Personal support and patient counseling $(\mathrm{H}=117.883, \mathrm{P}<0.001)$, domain 6- Professionalization and improving the quality of spiritual care $(\mathrm{H}=95.177 . \mathrm{P}<0.001)$ and overall competence $(\mathrm{H}=134.219$. $\mathrm{P}<0.001)$

Table 2 shows that $66 \%$ of the nurses belonged to the age group of $20-30$ years, $28 \%$ had scored less than $25^{\text {th }}$ percentile (chi square $=1.36$, not significant). $64 \%$ were married, $28 \%$ had scored less than $25^{\text {th }}$ percentile (chi square $=2.2$, not significant). With regard to religion, $82 \%$ of nurses were Christians, and $20 \%$ of them scored more than $75^{\text {th }}$ percentile. Majority of the nurses $(68 \%)$ were diploma holders in nursing and an equal percentage $(10 \%)$ of diploma and degree holders in nursing had scored more than $75^{\text {th }}$ percentile (chi square $=3.58$, not significant). Most of the nurses (38\%) had an experience of 2-5 years. (chi square $=3.8$, not significant). $90 \%$ of the nurses did not have any previous exposure to spiritual care training programme (chi square $=7.57$, significant)

Figure 1 indicates the comparison of overall spiritual care competence of nurses before and after spiritual care training program.

\section{DISCUSSION}

The 10 hours training program that included power point presentations and group works was found to be effective in significantly improving the spiritual care competence of nurses. Nurses did not differ significantly in their attitude to patient spirituality between pre-test and post test 1 . It can be inferred that a change in attitude usually needs more time to develop. In all other domains, a significant increase in competence of nurses was noted from pre test to post-test showing the effectiveness of training program.

Nurses competence in spiritual care gives a holistic perspective to patient care. A well planned training program gives more clarity to the concept of spiritual care and nurses role in various domains of spiritual care for patients. A study conducted by Burkhart L, William Schmidt has found a statistically significant increase in nursing students' perceived ability in providing spiritual care, particularly in complex family clinical situations before and after a planned training program ${ }^{7}$.

A qualitative study has explored the perceived impact of the study unit Spiritual Coping in Illness and Care on qualified nurses $^{8}$. Participants found the study unit as a resource for updating their knowledge on spirituality in care and increased self-awareness of their own spirituality and nursing care. They acknowledged their role as change agents in order to implement holistic care in collaboration with the multidisciplinary team. Recommendations were proposed to integrate the spiritual dimension in education and patient care. 
Table 1: Comparison of domain wise and overall competence of nurses in spiritual care competence in pre test and post test 1, post test 2 and post test 3

\begin{tabular}{|c|c|c|c|c|c|c|c|}
\hline $\begin{array}{r}\text { Sl } \\
\text { no. }\end{array}$ & Parameter/domain & Group & Median & Mean & $\mathrm{SE}$ & $\begin{array}{c}\text { Percentile } 25- \\
75 \\
\end{array}$ & Statistical details \\
\hline \multirow[t]{4}{*}{1} & \multirow{4}{*}{$\begin{array}{c}\text { Domain } 1 \\
\text { Attitude towards patient } \\
\text { spirituality }\end{array}$} & Pre test & 15 & 14.36 & 0.25 & $13-16$ & \multirow{4}{*}{$\begin{array}{c}\mathrm{H}=94.602 \\
\mathrm{P}<0.001\end{array}$} \\
\hline & & Post test 1 & 16 & 14.74 & 0.48 & $13-17$ & \\
\hline & & Post test 2 & 17 & 16.52 & 0.3 & $14.750-18$ & \\
\hline & & Post test 3 & 19 & 19.16 & 0.21 & $19-20$ & \\
\hline \multirow[t]{4}{*}{2} & \multirow{4}{*}{$\begin{array}{c}\text { Domain } 2 \\
\text { Communication }\end{array}$} & Pre test & 6 & 6.54 & 0.23 & $5-8$ & \multirow{4}{*}{$\begin{array}{c}\mathrm{H}=69.765 \\
\mathrm{P}<0.001\end{array}$} \\
\hline & & Post test 1 & 8 & 7.58 & 0.22 & $6.750-9$ & \\
\hline & & Post test 2 & 9 & 8.6 & 0.16 & $8-9$ & \\
\hline & & Post test 3 & 9 & 9 & 0.09 & $9-9$ & \\
\hline \multirow[t]{4}{*}{3} & \multirow{4}{*}{$\begin{array}{c}\text { Domain } 3 \\
\text { Assessment and } \\
\text { implementation of } \\
\text { spiritual care }\end{array}$} & Pre test & 17 & 16.74 & 0.62 & $13-20$ & \multirow{4}{*}{$\begin{array}{c}H=113.160 \\
P<0.001\end{array}$} \\
\hline & & Post test 1 & 21 & 19.74 & 0.75 & $18-23$ & \\
\hline & & Post test 2 & 23 & 22.48 & 0.57 & $19.750-26$ & \\
\hline & & Post test 3 & 28 & 27.74 & 0.26 & $27-29$ & \\
\hline \multirow[t]{4}{*}{4} & \multirow{4}{*}{$\begin{array}{l}\text { Domain } 4 \\
\text { Referral }\end{array}$} & Pre test & 9 & 9.1 & 0.27 & $8-10$ & \multirow{4}{*}{$\begin{array}{c}\mathrm{H}=89.740 \\
\mathrm{P}<0.001\end{array}$} \\
\hline & & Post test 1 & 11 & 10.5 & 0.42 & $9-12.250$ & \\
\hline & & Post test 2 & 12 & 12.16 & 0.25 & $11-13.250$ & \\
\hline & & Post test 3 & 13 & 13.58 & 0.2 & $13-14$ & \\
\hline \multirow[t]{4}{*}{5} & \multirow{4}{*}{$\begin{array}{c}\text { Domain } 5 \\
\text { Personal support and } \\
\text { patient counselling }\end{array}$} & Pre test & 17 & 17.52 & 0.49 & $15-20$ & \multirow{4}{*}{$\begin{array}{c}H=117.883 \\
P<0.001\end{array}$} \\
\hline & & Post test 1 & 22 & 20.82 & 0.76 & $19-25$ & \\
\hline & & Post test 2 & 26 & 24.86 & 0.45 & $23-27$ & \\
\hline & & Post test 3 & 28 & 27.16 & 0.28 & $26.750-29$ & \\
\hline \multirow[t]{4}{*}{6} & \multirow{4}{*}{$\begin{array}{c}\text { Domain } 6 \\
\text { Professionalization and } \\
\text { improving the quality of } \\
\text { professional care }\end{array}$} & Pre test & 15 & 15.7 & 0.68 & $12-20$ & \multirow{4}{*}{$\begin{array}{c}\mathrm{H}=95.177 \\
\mathrm{P}<0.001\end{array}$} \\
\hline & & Post test 1 & 21 & 20.28 & 0.8 & $19-24$ & \\
\hline & & Post test 2 & 21 & 21.22 & 0.48 & $19-23$ & \\
\hline & & Post test 3 & 26 & 25.9 & 0.31 & $24-27$ & \\
\hline \multirow[t]{4}{*}{7} & \multirow{4}{*}{$\begin{array}{l}\text { Overall spiritual care } \\
\text { competence of nurses }\end{array}$} & Pre test & 78 & 79.96 & 1.86 & $70-89.250$ & \multirow{4}{*}{$\begin{array}{c}H=134.219 \\
P<0.001\end{array}$} \\
\hline & & Post test 1 & 96 & 93.38 & 2.97 & $89.750-106$ & \\
\hline & & Post test 2 & 109 & 105.84 & 1.56 & $97.750-113$ & \\
\hline & & Post test 3 & 124 & 122.54 & 0.624 & $118.750-126$ & \\
\hline
\end{tabular}

Table 2: Association of spiritual care competence of nurses with selected demographic variables

\begin{tabular}{|c|c|c|c|c|c|c|c|c|c|}
\hline \multirow{3}{*}{ Sl no } & \multirow{3}{*}{ Demographic variables } & \multicolumn{6}{|c|}{ Spiritual care competence } & \multirow{3}{*}{$\begin{array}{l}\text { Chi } \\
\text { square }\end{array}$} & \multirow{3}{*}{$P$ value } \\
\hline & & \multicolumn{2}{|c|}{$\begin{array}{c}<25 \text { percentile } \\
(<70)\end{array}$} & \multicolumn{2}{|c|}{$\begin{array}{c}25-75 \text { percentile } \\
(71-90)\end{array}$} & \multicolumn{2}{|c|}{$\begin{array}{l}>75 \text { percentile } \\
(>90)\end{array}$} & & \\
\hline & & No & $\%$ & No & $\%$ & No & $\%$ & & \\
\hline \multirow[t]{3}{*}{1} & Age & & & & & & & \multirow[t]{3}{*}{1.36} & 0.5 \\
\hline & $20-30$ & 8 & 16 & 17 & 34 & 8 & 16 & & NS \\
\hline & $31-50$ & 6 & 12 & 9 & 18 & 2 & 4 & & \\
\hline \multirow[t]{3}{*}{2} & Marital status & & & & & & & \multirow[t]{3}{*}{2.20} & \multirow{3}{*}{$\begin{array}{l}0.33 \\
\text { NS }\end{array}$} \\
\hline & Married & 11 & 22 & 16 & 32 & 5 & 10 & & \\
\hline & Unmarried & 3 & 6 & 10 & 20 & 5 & 10 & & \\
\hline \multirow[t]{3}{*}{3} & Religion & & & & & & & \multirow[t]{3}{*}{4.14} & \multirow{3}{*}{$\begin{array}{l}0.12 \\
\text { NS }\end{array}$} \\
\hline & Hindu & 5 & 10 & 3 & 6 & 1 & 2 & & \\
\hline & Christian & 9 & 18 & 23 & 46 & 9 & 18 & & \\
\hline \multirow[t]{3}{*}{4} & $\begin{array}{l}\text { Professional } \\
\text { qualification }\end{array}$ & & & & & & & \multirow[t]{3}{*}{3.58} & \multirow[t]{3}{*}{$\begin{array}{l}0.16 \\
\text { NS }\end{array}$} \\
\hline & GNM & 12 & 24 & 17 & 34 & 5 & 10 & & \\
\hline & B.Sc. and above & 2 & 4 & 9 & 18 & 5 & 10 & & \\
\hline \multirow[t]{5}{*}{5} & Duration of experience & & & & & & & \multirow[t]{5}{*}{3.8} & \multirow{5}{*}{$\begin{array}{l}0.7 \\
\text { NS }\end{array}$} \\
\hline & Less than 1 year & 0 & 0 & 4 & 8 & 1 & 2 & & \\
\hline & $1-2$ years & 2 & 4 & 5 & 10 & 2 & 4 & & \\
\hline & $2-5$ years & 5 & 10 & 10 & 20 & 4 & 8 & & \\
\hline & $>5$ years & 7 & 14 & 7 & 14 & 3 & 6 & & \\
\hline \multirow[t]{3}{*}{6} & $\begin{array}{c}\text { Prior exposure to } \\
\text { spiritual care training }\end{array}$ & & & & & & & \multirow[t]{3}{*}{7.57} & \multirow[t]{3}{*}{$\begin{array}{c}0.02 \\
S\end{array}$} \\
\hline & Yes & 4 & 8 & 1 & 2 & 0 & 0 & & \\
\hline & No & 10 & 20 & 25 & 50 & 10 & 20 & & \\
\hline
\end{tabular}




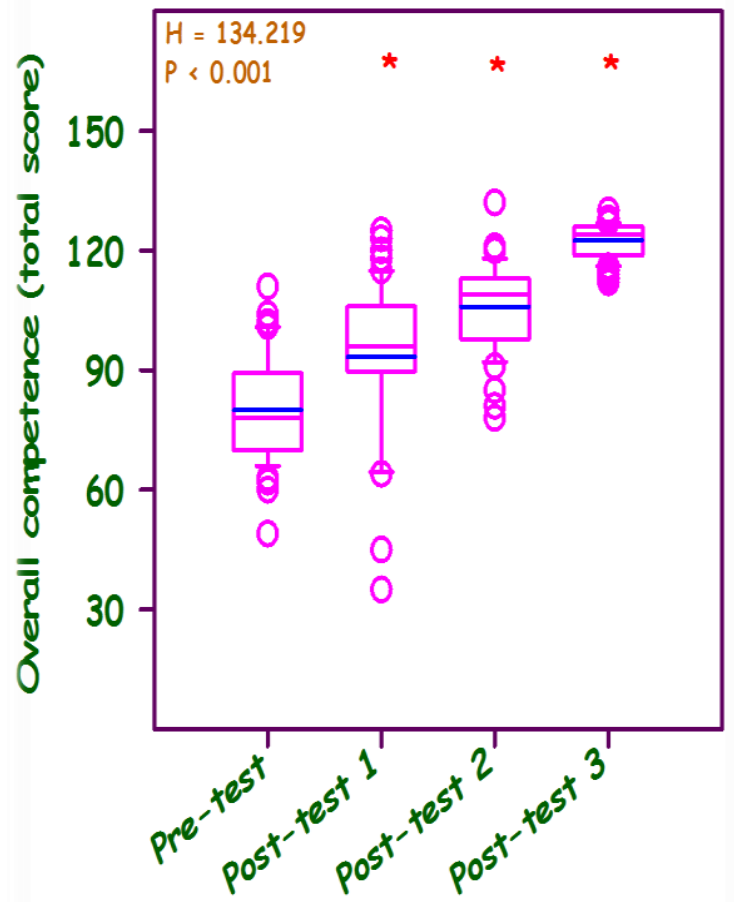

Figure 1: Comparison of overall spiritual care competence of nurses before and after spiritual care training program The middle pink line is median and the blue line is mean $(\mathrm{n}=50$ each). The $\mathrm{H}$ and $\mathrm{p}$ values are by Kruskal Wallis one way analysis of variance on ranks. *significantly different from pre test

\section{CONCLUSION}

The study has shown positive and encouraging results with regard to the effectiveness of spiritual care training program on improving spiritual care competence of nurses. Further studies can be planned with an experimental design with more sample size.

\section{REFERENCES}

1. Taylor EJ, Iris M, Khaled B, Triin A, Floyd P. Efficacy of a self study program to teach spiritual care. J Clinical Nursing 2008; 18: 1131- 40

2. Baldacchino DR. Nursing competencies for spiritual care. J Clinical Nursing 2006; 15(7): 885-96

3. Khatry $\mathrm{S}$ et al. Holistic approach to management of asthma. Int.J.Res.Ayurveda Pharm 2010; 1(2):367-383

4. Sharma KS. Nursing research and statistics. Elsevier private ltd. $4^{\text {th }}$ ed, 2014,101
5. VanLeeuwen R, Tiesinga LJ, Middel B, Post D, Jochemsen $\mathrm{H}$. The validity and reliability of an instrument to assess nursing competencies in spiritual care. J Clinical Nursing 2009 ; 18: 2857-69

6. VanLeeuwen R, Cusveller B. Nursing competencies for spiritual care. J Advanced Nursing 2004; 48(3) :234-46

7. Burkhart L, Schmidt. Measuring effectiveness of a spiritual pedagogy in nursing education. J Professional Nursing 2012; 28(5) : 315-21

8. Baldacchino DR. Teaching on spiritual care: the perceived impact on qualified nurses. Nurse education in practice 2011; 11(1):47-53.

\section{Cite this article as:}

K.R. Anoopa et al. Spiritual care competence of nurses: A pre experimental study. Int. J. Res. Ayurveda Pharm. 2017;8(3):120-123 http://dx.doi.org/10.7897/2277-4343.083156

Disclaimer: IJRAP is solely owned by Moksha Publishing House - A non-profit publishing house, dedicated to publish quality research, while every effort has been taken to verify the accuracy of the content published in our Journal. IJRAP cannot accept any responsibility or liability for the site content and articles published. The views expressed in articles by our contributing authors are not necessarily those of IJRAP editor or editorial board members. 